\title{
Preliminary Phytochemical Screening and GC-MS Analysis of Aqueous and Ethanolic Extracts of Amaranthus spinosus Leaves
}

\author{
Solomon A. Mamuru' ${ }^{1, *}$, Iliya Kaigamma ${ }^{1}$, Muluh E. Khan ${ }^{2}$ \\ ${ }^{1}$ Department of Chemistry, Adamawa State University, Mubi, Nigeria. \\ ${ }^{2}$ Department of Chemistry, University of Agriculture, Makurdi, Nigeria.
}

\section{ART I C LE DETAILS}

Article history:

Received 10 December 2018

Accepted 21 May 2019

Available online 01 August 2019

\section{Keywords:}

Amaranthus spinosus

Phytochemical Screening

Phytoconstituents

\begin{abstract}
A B S T R A C T
Herein we report the phytochemical screening and gas chromatography-mass spectroscopy (GC-MS) of Amaranthus spinosus an annual plant that grows wildly in Nigeria, using standard methods. Dried powdered leaves of the plant were subjected to cold maceration in two polar solvents, water and ethanol. The phytochemical screening of the water extract reveals the presence of bioactive constituents viz. alkaloids, glycosides, flavonoids, tannins, saponins, terpenoids, steroids, anthraquinones, phenols, carbohydrates, proteins, and fats. While GC-MS analysis reveals peaks that represent ten different chemical compounds in the plant, two prominent compounds were identified: 1,5-methano-1H,7H,11Hfuro[3,4-g]pyrano[3,2-b]xanthene-7,15-dione,3,3a,4,5-tetrahydro-8-hydroxy-3,3,11,11-tetramethyl-1, 13-bis(3-methyl-2-buten-1-yl)-,(1R,3aS,5S,14aS)- and 7,11-hexadecadienal as the most abundant constituents while the least abundant compounds were the 9-oxabicyclo[6.1.0] nonane and 7-octen-2one.
\end{abstract}

\section{Introduction}

Amaranthus spinosus originates probably from lowland tropical South and Central America and was introduced into other warmer parts of the world from about $1700 \mathrm{AD}$ onwards. At present it occurs in all tropical and subtropical regions, including tropical Africa, often gregariously and as a weed. It is sometimes found in temperate zones as well. It is rarely cultivated [1].

Nigeria is endowed by varieties of plants and animals due to its biodiversity. In ancient times just like any other country in the world, Nigerians use plant products as a major source of primary health care before the advent of the modern chemotherapeutic drugs and hitherto.

Plants are known to contain some bioactive constituents which are responsible for physiological and metabolic actions in the human system. These phytochemicals components include: alkaloids, steroids, tannins, terpenoids, flavonoids, phenols, glycosides, carbohydrates, and fats. They work in conjunction with fibers and nutrients to form an integral part of defense mechanism against various ailments [2-4].

Amaranthus spinosus in Nigeria is regarded as weed or at best animal feeds, very few use it for medicinal purposes and researches have shown that the plant contains diaphoretic, diuretic, emollient, febrifuge and in the treatment of internal bleedings, diarrhea, excessive menstruation, snake bite, boils, stomach disorder, ulcerated mouth, virginal discharge, nose bleed and wounds. A paste of root is used in the treatment of menorrhagia, gonorrhea, eczema and colic. The root juice is used to treat fever, urinary problems, diarrhea and dysentery, plant sap as an eye wash to treat ophthalmic and convulsion in children. In animals it is said to increase milk production as reported by Chondhary [2], he further stated that the plant has been used to treat various symptoms associated with nutritional deficiencies, having sedative and refrigerant properties. It was also reported to have antiparasitic effect, as a spermatogenic agent (increase sperm production), has analgesic and antiprotozoal properties [5].

The use of Amaranthus spinosus as a precursor in the synthesis of metal nanoparticles has been reported; the plant phytochemicals are said to be responsible for reducing and capping of the resultant nanoparticles $[6,7]$. Therefore, an understanding of the chemical constituents present in the plant will go a long way in describing the reaction mechanism of the synthesis since there is no known general acceptable mechanism. It is 


\section{Results and Discussion}

Amaranthus spinosus is a medicinal plant as well as precursor in the synthesis of metal nanoparticles as reported by researchers, it is found to contain alkaloids, anthraquinones, flavonoids, saponins, tannins, glycosides and essential oils [9] which make it useful for antimicrobial, spasmolytic and analgesic activities [2]. In this study, the presence of these phytochemicals was confirmed as well as proteins, however fats were added to the number of the active components as shown in its aqueous and ethanol extracts (Table 1).

Table 1 Phytoconstituents of Amaranthus spinosus water and ethanol leaves extracts

\begin{tabular}{lll}
\hline Phytoconstituents & Ethanol & Water \\
\hline Carbohydrates(reducing and non-reducing sugar) & + & + \\
Proteins & + & + \\
Amino acids & + & + \\
Cardiac glycosides & + & + \\
Anthraquinones & + & + \\
Saponins & + & + \\
Tannins & + & + \\
Flavonoids & + & + \\
Terpenoids & + & + \\
Alkaloids & + & + \\
Phenols & + & + \\
Fats & + & + \\
\hline
\end{tabular}

The gas chromatogram (Fig. 1) of aqueous leaves extract shows peaks which indicated the presence of ten different chemical constituents when compared to the mass spectra of the NIST library as presented in Table 2.

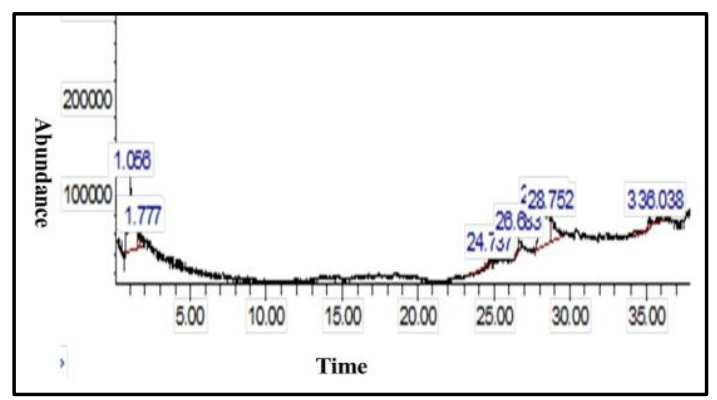

Fig. 1 Gas chromatogram of Amaranthus spinosus aqueous leaves extract

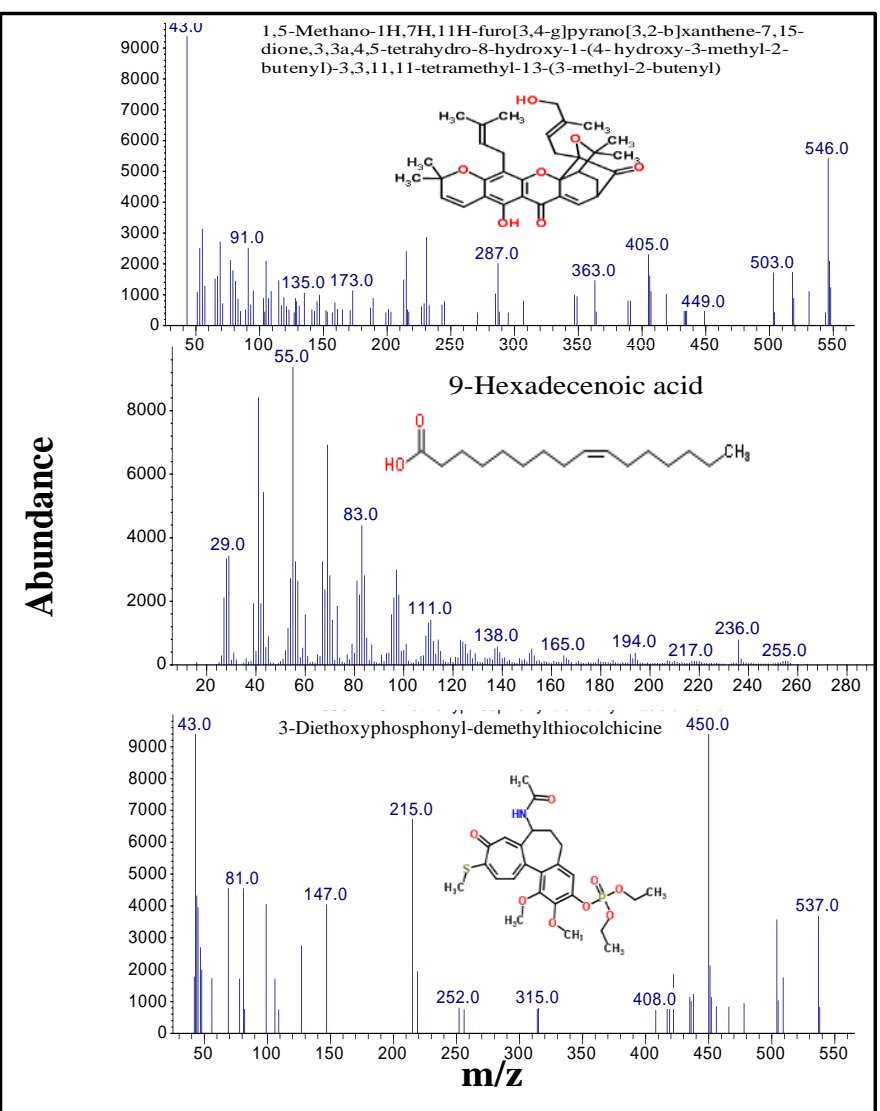

Fig. 2 Mass spectra of selected compounds eluted from Amaranthus spinosus extract https://doi.org/10.30799/jnpr.071.19050201
The gas chromatogram showed the relative concentrations of various compounds getting eluted as a function of retention time in minutes while the relative concentrations of the components present in the plant is indicated by the peak heights. The mass spectrometer analyzed the compounds eluted at different times to identify the nature and structure of the compounds. The large compound fragments into smaller compounds giving rise to appearance of peaks at different $\mathrm{m} / \mathrm{z}$ ratios. These mass spectra are fingerprint of compounds which can be identified from the data library [10]. The mass spectra of some selected compounds are presented in Fig. 2. The two prominent compounds identified were 1,5-Methano-1H,7H,11H-furo[3,4-g]pyrano[3,2-b]xanthene-7,15-dione, 3,3a,4,5-tetra hydro-8-hyd-roxy-3,3,11,11-tetramethyl-1,13-bis(3-methyl2-buten-1-yl) -,(1R, 3aS, 5S, 14aS)- and 7,11-hexadecadienal as the most abundant constituents as revealed by their peak areas of $37.10 \%$ and $35.99 \%$ at retention times of 1.059, 28.278 minutes respectively, while the least abundant compounds were the 9-0xabicyclo[6.1.0]nonane and 7octen-2-one, with $0.22 \%$ and $0.61 \%$ peak areas at 35.248 minutes and 26.686 minutes retention times respectively (Table 2). Muneer et. al. [11] also worked on GC-MS of ethanol extract of Amaranthus spinosus, their study reveals the presence of 28 different chemicals, the closest in similarity to what we obtained is n-hexadecanoic acid (MF: $\mathrm{C}_{16} \mathrm{H}_{32} \mathrm{O}_{2}$; $\mathrm{MW}$ : 256) as against our 9-hexadecenoic acid (MF: $\mathrm{C}_{16} \mathrm{H}_{30} \mathrm{O}_{2} ; \mathrm{MW}: 254$ ).

Table 2 Constituents and phytochemical classes of Amaranthus spinosus

\begin{tabular}{|c|c|c|c|c|c|c|}
\hline $\begin{array}{l}\text { Peak } \\
\text { No. }\end{array}$ & $\begin{array}{l}\text { RT } \\
(\min )\end{array}$ & $\begin{array}{l}\text { Area } \\
(\%)\end{array}$ & $\begin{array}{l}\text { Chemical } \\
\text { Compounds }\end{array}$ & $\begin{array}{l}\text { Molecular } \\
\text { Formula }\end{array}$ & $\begin{array}{l}\text { MW } \\
\text { (g/mol) }\end{array}$ & $\begin{array}{l}\text { Associated } \\
\text { Phytochemical }\end{array}$ \\
\hline 1. & 1.06 & 37.1 & $\begin{array}{l}\text { 1,5-Methano- } \\
\text { 1H,7H,11H-furo[3,4- } \\
\text { g]pyrano[3,2- } \\
\text { b]xanthene-7,15- } \\
\text { dione,3,3a,4,5- } \\
\text { tetrahydro-8- } \\
\text { hydroxy-3,3,11,11- } \\
\text { tetramethyl-1,13- } \\
\text { bis(3-methyl-2- } \\
\text { buten-1-yl)- } \\
\text {,(1R,3aS,5S,14aS)- }\end{array}$ & $\mathrm{C}_{33} \mathrm{H}_{38} \mathrm{O}_{7}$ & 546 & Alkaloid \\
\hline 2. & 1.60 & 3.07 & $\begin{array}{l}\text { 3-[2- } \\
\text { Dimethylamino-1- } \\
\text { hydroxy] ethyl, } \\
\text { carbazole }\end{array}$ & $\mathrm{C}_{18} \mathrm{H}_{22} \mathrm{~N}_{2} \mathrm{O}_{2} \mathrm{~S}$ & 330 & Flavonoids \\
\hline 3. & 24.7 & 2.43 & $\begin{array}{l}3,7 \text { Dihydropurine } \\
2,6 \text { dione, } \\
7(2 \text { dimethylamino } \\
\text { ethyl 1,3 dimethyl } \\
\text { cyclobutylsilane }\end{array}$ & $\mathrm{C}_{5} \mathrm{H}_{4} \mathrm{~N}_{4} \mathrm{O}_{2}$ & 152 & $\begin{array}{l}\text { Alkaloid } \\
\text { glycoside }\end{array}$ \\
\hline 4. & 26.7 & 0.61 & 7-Octen-2-one & $\mathrm{C}_{8} \mathrm{H}_{14} \mathrm{O}$ & 126 & Steroid \\
\hline 5. & 28.3 & 36.0 & $\begin{array}{l}\text { 7,11-Hexadeca } \\
\text { dienal }\end{array}$ & $\mathrm{C}_{16} \mathrm{H}_{28} \mathrm{O}$ & 236 & Alkaloid \\
\hline 6. & 28.8 & 14.1 & $\begin{array}{l}\mathrm{N} \text {-[3-methylamino } \\
\text { propyl] aziridine }\end{array}$ & $\mathrm{C}_{6} \mathrm{H}_{14} \mathrm{~N}_{2}$ & 114 & Alkaloid \\
\hline 7. & 35.3 & 0.22 & $\begin{array}{l}\text { 9-0xabicyclo[6.1.0] } \\
\text { nonane }\end{array}$ & $\mathrm{C}_{8} \mathrm{H}_{14} \mathrm{O}$ & 128 & Terpenoids \\
\hline 8. & 35.3 & 1.09 & 9-hexadecenoic acid & $\mathrm{C}_{16} \mathrm{H}_{30} \mathrm{O}_{2}$ & 254 & Fatty acid \\
\hline 9. & 36.0 & 2.17 & 9-Octadecenal & $\mathrm{C}_{18} \mathrm{H}_{34} \mathrm{O}$ & 266 & Flavonoids \\
\hline
\end{tabular}

\section{Conclusion}

Phytoconstituents of aqueous and ethanolic leaves extract of Amaranthus spinosus was successfully screened using standard procedures. The result shows the presence of alkaloids, anthraquinones, flavonoids, saponins, tannins, glycosides, proteins, amino acids and fats. GC-MS analysis reveals 9-oxabicyclo [6.1.0] nonane, 9-hexadecenoic acid 9-octadecenal, 7-Octen-2-one, 7,11-hexadecadienal and $\mathrm{N}$-[3methylaminopropyl] aziridine as some of the chemical compounds present in the plant.

\section{Acknowledgement}

The authors will like to thank Adamawa State University for providing the facilities used in carrying out this research.

\section{References}

[1] P.C.M. Jansen, Amaranthus Spinosus L., Record from PROTA 4, PROTA (Plant Resources of Tropical Africa), Wageningen, Netherlands, 2004. 
[2] V. Chondhary, Medicinal use of spiny amaranth (Amaranthus spinosus), Abhinav Nature Conservation, India, 2017.

[3] Z. Maiyo, R. Ngure, J. Matasyoh, R. Chepkorir, Phytochemical constituents and antimicrobial activity of leaf extract of three Amaranthus plant species, Afr. J. Biotechnol. 9(21) (2010) 3178-3182.

[4] K.V. Sable, R.R. Saswade, Preliminary phytochemical analysis of Amaranthus spinosus, Int. J. Life Sci. 5(4) (2017) 742-745.

[5] G. Ezengige, Spiny amaranth (Amaranthus spinosus) is real medicicne, 2016. www.healthbubbles.com (Accessed on: 21.01.2016)

[6] R.K. Das, N. Gogoi, P.J. Babu, P. Sharma, C. Mahanta, U. Bora, The synthesis of gold nanoparticles using Amaranthus spinosus leaf extract and study of their optical properties, Adv. Mat. Phys. Chem. 2 (2012) 275-281.

[7] H. Muthukumar, M. Matheswaran, Amaranthus spinosus leaf extract mediated
FeO nanoparticles: Physicochemical traits, photocatalytic and antioxidant activity, ACS Sust. Chem. Eng. 3(12) (2015) 3149-3156.

[8] J. Harbone, Phytochemical methods, Chapman and Hall Publications, London, UK, 1992.

[9] D.P. Khanal, B. Raut, K.S. Dangol, Phytochemical screening, pharmacognostic evaluation and biological activity of Amaranthus spinosus L., J. Manm. Memo. Inst. Health Sci. 1(4) (2015) 29-34.

[10] N. Janakiraman, M. Johnson, S.S. Sahaya, GC-MS analysis of bioactive constituents of peristrophe bicalyculata (Retz.) Nees. (Acanthaceae), Asian Pac. J. Trop. Biomed. 2(1) (2012) S46-S49.

[11] J.M. Ahamath, J. Sirajudeen, Phytochemical studies and antibacterial activities of Amaranthus spinosus L., World J. Pharm. Pharm. Sci. 3(12) (2014) 1692 1697. 